
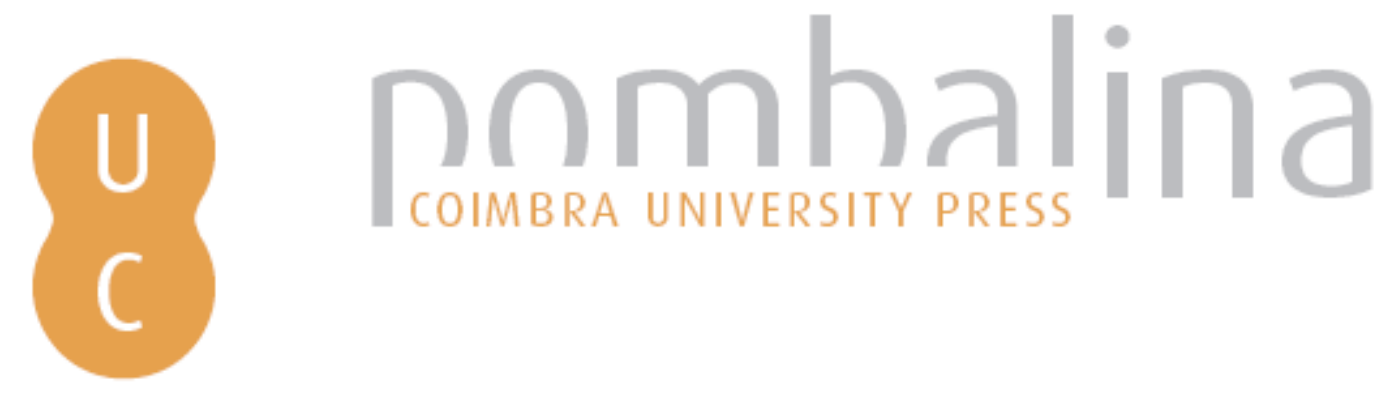

\title{
Unha tardiña en Mitilene de Andrés Pociña, unha reconstrucción do mundo sáfico
}

Autor(es): $\quad$ Amado Rodríguez, $\mathrm{M}^{\mathrm{a}}$ Teresa

Publicado por: Imprensa da Universidade de Coimbra; Annablume

URL

persistente: URI:http://hdl.handle.net/10316.2/40917

DOI: $\quad$ DOI:https://doi.org/10.14195/978-989-26-1298-0_11

Accessed : $\quad$ 26-Apr-2023 15:25:52

A navegação consulta e descarregamento dos títulos inseridos nas Bibliotecas Digitais UC Digitalis, UC Pombalina e UC Impactum, pressupõem a aceitação plena e sem reservas dos Termos e Condições de Uso destas Bibliotecas Digitais, disponíveis em https://digitalis.uc.pt/pt-pt/termos.

Conforme exposto nos referidos Termos e Condições de Uso, o descarregamento de títulos de acesso restrito requer uma licença válida de autorização devendo o utilizador aceder ao(s) documento(s) a partir de um endereço de IP da instituição detentora da supramencionada licença.

Ao utilizador é apenas permitido o descarregamento para uso pessoal, pelo que o emprego do(s) título(s) descarregado(s) para outro fim, designadamente comercial, carece de autorização do respetivo autor ou editor da obra.

Na medida em que todas as obras da UC Digitalis se encontram protegidas pelo Código do Direito de Autor e Direitos Conexos e demais legislação aplicável, toda a cópia, parcial ou total, deste documento, nos casos em que é legalmente admitida, deverá conter ou fazer-se acompanhar por este aviso.

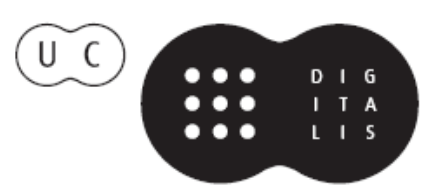




\section{O Livro do Tempo: \\ Escritas e reescritas}

\section{Teatro Greco-Latino e sua recepção II}

Maria de Fátima Silva, Maria do Céu

Fialho \& José Luís Brandão (coords.)

IMPRENSA DA UNIVERSIDADE DE COIMBRA 


\title{
Unha tardiña en Mitilene de Andrés Pociña, unha RECONSTRUCCIÓN DO MUNDO SÁFICO (An evening at Mitilene by Andrés Pociña, a reconstruction of the Sapphic world)
}

\author{
Ma Teresa Amado Rodríguez (mariateresa.amado@usc.es) \\ Universidade de Santiago de Compostela
}

\begin{abstract}
Resumo - Unha tardiña en Mitilene recrea o universo sáfico no marco da vida cotiá partindo dos fragmentos conservados da autora. Neste traballo estudamos as diferentes formas que emprega Pociña para integrar os textos da poeta grega como hipotextos da súa obra.

Palabras chave - Safo, Pociña, teatro, tradición clásica, estudos de recepción.
\end{abstract}

Aвstract - Unha tardina en Mitilene reproduces the Sapphic universe within the framework of daily life using the fragments kept from the authoress. In this paper we analyse how Pociña integrates the texts written by the Greek poetess as hypotexts of her work.

Keywords - Sappho, Pociña, theatre, classical tradition, reception studies.

Cando pases á beira da tumba eolia, estranxeiro, non digas

Que eu, a cantora de Mitilene, morta estou. A tumba construírona mans de homes, e tales obras de mortais corren veloces ao esquecemento. Pero se verificas en min a calidade das Musas, -nos meus nove libros dediqueilles cadansúa florSaberás que eu esquivei as tebras do Hades, e non haberá sol que descoñeza o nome da poeta Safo.

\section{Outra vez Safo}

Seis séculos despois da morte de Safo, o poeta Marco Tulio Laurea escribía este fermosísimo epitafio no que o último verso agoira memoria eterna para a gran poeta eolia ${ }^{1}$. Vinte séculos pasaron desde aquela e Unha tardiña en Mitilene de Andrés Pociña é unha proba máis non só da perdurabilidade do seu recordo, senón tamén do poder de sedución que o seu universo vital segue exercendo no mundo de hoxe, a xulgar polo éxito co que un público entusiamado acolleu cada unha das representacións da obra que se fixeron en España e Portugal ${ }^{2}$.

\footnotetext{
${ }^{1} A P 7.17$. A tradución é miña.

${ }^{2}$ A obra estreouse o 25 de xuño de 2010 na Aula Magna da Facultade de Filosofía e Letras de Granada e desde aquela representouse en varios lugares de Andalucía e no Museu Machado de Castro de Coimbra. O 14 de abril de 2015 volveu ao escenario onde se estreara.
} 
Non é a primeira vez que o autor encontra en Safo a inspiración para os seus escritos en prosa ou en verso, artigos, relatos curtos e poemas, movido pola adoración sen límites que confesa sentir por esa muller, á que, por ser referente de moitísimas escritoras, tamén escritores, de todos os tempos, ten cualificado de 'nai poética universal's. 'Nai', así en galego, porque esa é a lingua na que Pociña dá forma ás súas creacións literarias e na que, polo tanto, orixinalmente escribiu este texto, igual que as súas outras pezas dramáticas de tema clásico, Medea en Camariñas e Antígona ante os xuices. As tres foron publicadas xuntas en versión castelá en $2015^{4}$, de Unha tardiña en Mitilene editouse tamén unha tradución portuguesa ${ }^{5}$, pero, non sendo $M e d e a^{6}$, das outras dúas lamentablemente permanecen inéditas as versións na lingua na que foron concibidas. Con todo, este estudo está feito sobre o texto galego inédito que o autor nos facilitou. Para el o noso agradecemento ${ }^{7}$.

\section{A VIDA COTIÁ COMO MARCo}

A partir dos fragmentos de Safo e dos controvertidos testemuños sobre ela que a Antigüidade nos transmitiu, os filólogos debaten desde hai séculos a relación da poeta coas destinatarias da súa poesía, o contexto no que se interpretaban os poemas e a función que estes tiñan no marco das representacións, non sempre tendo en conta a necesaria perspectiva antropolóxica e histórica e moitas veces coas restricións impostas por criterios morais inapropiados. Por todo iso nin se chegou, nin poida que se chegue nunca, a unha conclusión irrefutable sobre a famosa cuestión sáfica ${ }^{8}$. Pero Pociña, desposuído de calquera prexuízo moral e con escaso interese polos aspectos máis estreitamente vencellados a un contexto desdebuxado polo tempo, centra a súa atención na persoa, na muller, poñendo en primeiro plano o amor e a dolor da ausencia, a traizón e os celos, en definitiva as experiencias e sentimentos inherentes á condición humana, e polo tanto universais e intemporais, que tan ben soubo expresar Safo nos seus versos. Isto non quere dicir que vaiamos atopar unha dislocación espacial ou temporal, como en Medea en Camariñas, o que desaparezan por completo os elementos polémicos da tradición, como a homosexualidade, ou como a visión

${ }^{3}$ Pociña Pérez 2007: 10. Unha exposición polo miúdo de toda a produción do autor arredor da figura de Safo pode verse en Pociña Pérez 2009a.

${ }^{4}$ Pociña Pérez 2015.

${ }^{5}$ Pociña Pérez 2011.

${ }^{6}$ Pociña Pérez 2004.

${ }^{7}$ As páxinas que citemos serán as desta versión inédita. Referirémonos a ela como Pociña $2009 b$, porque esa e a data que figura na dedicatoria. A numeración dos fragmentos de Safo é a da edición de Voigt 1971.

${ }^{8}$ Unha panorámica xeral sobre as cuatro liñas interpretativas analizadas á luz dos fragmentos en Lardinois 1994. 
do círculo sáfico, en palabras de $\mathrm{M}^{a}$ Fátima Silva, como "um grupo destinado a formar filhas de boas famílias para cumprirem a missão que a sociedade grega lhes atribuía, o matrimónio e a maternidade", senón que Lesbos e o mundo no que viviu Safo se integran na obra debuxando unha ambientación evocadora e envolvente, como marco necesario que acolle e sostén os elementos esenciais cunha naturalidade que evita calquera determinismo interpretativo. $\mathrm{O}$ patio dunha casa de Lesbos, de paredes brancas e testos verdes floridos de xeranios, acolle un grupo multicolor de rapazas novas e a súa mestra Safo, de idade xa madura e coa traza sobria que lle dá o seu atuendo branco ${ }^{10}$. É a atardecida dun día tórrido, as protagonistas parecen espertar do letargo e volver á vida cando a calor comeza a ceder. $\mathrm{Na}$ intimidade do ô̂kos o alivio que trae o xa próximo solpor invita á conversación relaxada, que pon ante os espectadores os aspectos máis triviais da convivencia. Polos fragmentos coñeciamos só o máis sublime e imperecedeiro do mundo de Safo e agora Pociña reconstrúe a súa vida cotiá coas miserias e debilidades nas que todos nos recoñecemos, os sentimentos menos nobres, as leas, os celos, as pequenas mentiras, o aburrimento, a fatiga das tarefas domésticas, o malestar físico. Así vemos, por exemplo, os enganos de Filenis, o cansazo de Telesipa despois dun pedazo caleando as paredes do patio, a Xirina bordando o seu enxoval, a Gonxila pintando os soportes dos testos, a Safo afectada polos efectos da calor ou ocupándose da compra diaria do peixe, ou como Mégara afea repetidamente os comportamentos das demais rapazas coa idea de gañar a atención preferente da mestra. Ao recrear este ambiente cotián tan alleo ao refinamento da lírica, que nos dá outra perspectiva da poeta menos idealizada, o autor emporiso non está renunciando á exquisitez do mundo sáfico dos fragmentos, senón que con gran habelencia establece varios tipos de relacións transtextuais entre estes e a súa obra, ofrecendo así unha imaxe da poeta e do seu arredor máis completa que aquela que a tradición nos deixou ${ }^{11}$.

\section{Coma un mosaico}

A forma máis explícita e evidente de facer presente o texto sáfico é a cita literal, integrada na obra como as teselas dun mosaico con técnicas diferentes.

O goce estético. Na máis simple, que atopamos xa nos primeiros momentos da conversa, a reprodución do fragmento ten como finalidade atender o requerimento de quen tan só desexa gozar do pracer de escoitalo, dar satifacción

\footnotetext{
${ }^{9}$ Silva 2012: 430.

${ }^{10} \mathrm{Na}$ obra é moi importante o aspecto visual e o contraste cromático, no só como elementos estéticos, senón como signos non verbais cargados de significado, como ben subliñou Romero Mariscal 2012: 204.

${ }^{11}$ Como sinalou Romero Mariscal 2012: 205: “El medio teatral proporciona el marco que permite hacer de los versos la auténtica figura del drama, al concentrar la atención y la inteligencia del auditorio sobre ellos".
} 
a quen busca únicamente o deleite estético. Así, mentres algunhas rapazas aínda ocupan as súas mans en rematar as actividades que require o mantemento da casa e outras xa descansan sentadas á beira da mestra, a serenidade do ambiente invita á conversación relaxada e Safo, aínda afectada pola dor de cabeza que lle produciu a calor, pregunta ás súas discípulas que poderían facer nesa reunión vespertina. A resposta xorde inmediatamente da boca de Mégara: "Podías recitarnos un pouco, señora. Por exemplo eses poemas que andabas a escribir esta mañá”, e as voces das outras axiña se unen entusiasmadas, dando mostras dunha adoración sen límites pola mestra. Pero, como sinalou Fátima Silva, na estratexia pedagóxica de Safo está a estimulación do empeño e o esmero ${ }^{12}$, e como os versos aos que se refire Mégara no foron traballados dabondo, a mestra non considera adecuado que sexan difundidos, nin sequera ante un auditorio tan reducido e íntimo. Entón é a propia discípula a que, gabando a capacidade expresiva de Safo, inclúe a primeira cita textual da obra, recordando con enorme compracencia estes versos:

Amor axitou as entrañas miñas

como un vento que baixa o monte abatendo as aciñeiras ${ }^{13}$.

Máis adiante será a propia autora, ao lle pedir Xirina que llea dea a coñecer un adianto do que está a compoñer para a súa próxima voda, a que reproduza o epitalamio: "Arriba a viga mestra, himeneo!"14, malia non estar completamente terminado, segundo ela di.

Unha variante desta técnica consiste en traspasar a propia Safo a unha das rapazas o protagonismo da recitación, polo xeral co pretexto do cansazo ou polo fastío de repetir sempre o mesmo. Así cando Mégara solicita que recite unha vez máis os versos da famosa Oda de Lonxino, a poeta deixa a Irana, a súa preferida, a que "os comprende mellor que ninguén" ${ }^{15}$, o honor de declamala.

A exégese. Pero ao longo da peza dramática a técnica vai variando. $\mathrm{O}$ autor recorre alternativamente a outros medios para integrar as citas que dan lugar a relacións transtextuais máis complexas. Nos momentos nos que a poeta se abandona aos recordos de experiencias pasadas e fai partícipes deles ás mozas, no medio do relato van xurdindo os versos inspirados pola peripecia amorosa, que así adquiren todo o seu sentido. O exemplo máis significativo atopámolo na historia de Atis, que a mestra, bastante celosa da súa intimidade, accede a

12 Silva 2012: 423.

${ }^{13}$ P. 25, fr. $47 \mathrm{~V}$.

${ }^{14}$ P. 33, fr. $111 \mathrm{~V}$.

${ }^{15}$ P. 30. De todas as rapazas é Irana a que ten unha sensibilidade máis exquisita e máis calidades para a creación poética. Safo nalgún momento da obra deixa entrever sentimientos por ela semellantes aos que tivo por Atis no seu día. 
contar ante a insistencia das discípulas. Nun longo parlamento vai debullando os detalles da relación que tanto a marcou e que foi un estímulo creador tan importante para ela pola intensidade dos sentimentos encontrados que lle fixo experimentar ${ }^{16}$. Ao desvelar os pormenores das súas vivencias máis íntimas e relacionar con eles os fragmentos da súa obra, a Safo de Pociña está facendo unha verdadeira exégese deses textos, contextualizándoos e desentrañando o seu verdadeiro significado, en definitiva desvelando o que a crítica intenta descubrir desde hai tantos séculos. Así nos percatamos de quen é a destinataria desta agresión verbal:

E morta xacerás, e non haberá un día nin un recordo de ti nin xamais no futuro: porque non participas das rosas de Pieria; mais, invisible mesmo na mansión de Hades, irás errante entre apagados mortos, caída do teu volo ${ }^{17}$.

Ata o momento só sabiamos por Plutarco da súa incultura e insensibilidade e tamén da súa opulencia ${ }^{18}$, pero a nosa Safo de ficción revela que os groseiros desprezos de Atis á súa poesía ("contestoume de xeito moi desairado que estaba dos meus versos ata o forro da cona. Perdoádeme, esas foron as súas verbas, nunca antes oídas na miña vida: ata o forro da cona"19), motivaron tan duras palabras.

O texto como inspiración. Unha terceira forma de integrar unha cita é utilizala como pretexto de estímulo para a inspiración artística. Conforme á tradición, Filenis refírese ao fogar que comparten con Safo como "esta residencia túa e das musas" ${ }^{20}$, divindades invocadas a miúdo polas rapazas quizais cun sentido cultual que vai máis alá dun xesto cotián ${ }^{21}$. Como corresponde a tal título, dentro da casa cultívanse as artes como parte da educación que prepara ás discípulas para a súa futura vida de esposas e nais, e Safo exerce permanentemente o seu maxisterio intentando facer proveitosa cualquera actividade, mesmo as desenvolvidas nos relaxados momentos de $l e c e{ }^{22}$. Por iso propón un

${ }^{16}$ A historia que conta Safo comprende desde o momento en que coñeceu a Atis, sendo case unha nena, ata o abandono. O recordo nostálxico das súas noites de amor na praia é a reelaboración dun relato breve do propio Pociña, "Solpor. Safo de Lesbos, 596 a.C." publicado en Pociña 2000: 15-18.

${ }^{17}$ P. 38, fr. 55 V. A supervivencia a través da participación no mundo da poesía é un valor común do auditorio de Safo. Esta memoria desempeña unha función semellante ao kléos da épica que tamén traspasa os límites da morte física. Vid. Aloni 1997: LXXII.

${ }^{18}$ Vid. Plu. 646e; $145 f$.

${ }^{19}$ P. 38.

${ }^{20}$ P. 31. A moisopólon dómos do fr.150 V.

${ }^{21}$ Así o suxire Silva 2012: 421: "ao autor não é estranho o sentido cultual que Afrodite e as Musas poderão ter em Safo".

22 Superada a idea da casa de Safo como un pensionado de señoritas, que Wilamowitz 
xogo poético educativo, alentando ao seu auditorio a que non se quede só no goce estético de escoitar un poema, senón que utilice a beleza da poesía para a creación literaria. Con isto busca ademáis estimular o espírito agonal que preside o desenvolvemento de todas as actividades no mundo grego como medio de acadar a excelencia. As rapazas deberán buscar unha continuación para os versos que ela recita:

Púxose xa a lúa

e as Pléiades; mediada vai

a noite, pasan as horas,

mais eu adormezo soa $^{23}$.

E aínda que a creación da súa mellor discípula, Irana, capaz de imitar á mestra con indiscutible calidade, probará a pertinencia do xogo e a eficacia do método, a reacción de Mégara dá conta dos riscos dunha rivalidade mal entendida contaminada polos celos, pois, empeñada en ser sempre a primeira para gañar a preferencia de Safo, a moza non dubida en facer trampa recitando como propios versos da poeta. Con este procedemento Pociña integra no texto dramático outro fragmento literal, ao tempo que advirte ao espectador sobre posibles efectos na peripecia da transmisión textual ${ }^{24}$ :

As estrelas arredor da fermosa lúa de novo agachan o seu resplandor cando na súa plenitude chea alumea a terra enteira...25.

Pero os versos de Safo son, en palabras do propio Pociña, "portadores de incontables sugerencias” ${ }^{26}$ e na súa casa cultívanse máis artes que a poesía, pois entre as súas estratexias pedagóxicas está procurar o desenvolvemento das habelencias nas que cada unha destaca. Gonxila, que vemos pintando o soporte dun testo, revélase tamén como a máis cualificada para a pintura artística e promete á mestra un cadro sobre o nacemento de Afrodita. A dificultade para captar a esencia da divindade queda resolta pola artista acudindo ao texto sáfico como fonte de inspiración para a súa obra, introducindo con este recurso os primeiros versos do Himno a Afrodita:

propuxera para defender a Safo das acusacións de homosexualidade, a escenificación de Pociña parece encaixar máis coa idea de Calame, para o que a educación que a poeta daba ás mozas as preparaba para seren adultas e integrárense na vida social. Vid. Calame 1996.

${ }^{23}$ P. 25 , fr. $168 \mathrm{~b}$ V.

${ }^{24}$ Vid. Silva 2012: 424.

${ }^{25}$ P. 25 , fr. $34 \mathrm{~V}$.

${ }^{26}$ Pociña 2009a: 371. 
Mais eu colocareime ante a táboa, coas pinturas, e comezarei a traballar recitando aqueles teus versos

"De polícromo trono, inmortal Afrodita

filla de Zeus que argallas intrigas, suplícoche:

nin a tormentos nin a angustias sometas,

señora, o corazón meu..."

Esa será a miña inspiración ${ }^{27}$.

Desta maneira o cadro será a materialización da epifanía da deusa que se reclama na seguinte estrofa, unha especie de continuación do poema, e as dúas artes amosaranse como partes complementarias dun todo harmónico.

\section{COMA Un PALIMPSESTO}

A cita literal non é a única forma de estar presente o texto Sáfico na obra de Pociña. Se no nivel da ficción os personaxes, por distintas razóns, reproducen con recorrencia os fragmentos, no nivel da creación entre estes e a obra dramática establécense unhas relacións de intertextualidade diferentes e máis complexas, pois o autor bota man dos materiais clásicos, reelabóraos imprimíndolles o seu selo persoal e obtén como resultado unha obra nova e orixinal que conserva as pegadas do texto anterior como se dun palimpsesto se tratase. En realidade é unha técnica semellante á que o autor emprega no seu "Comentario a seis fragmentiños de $\mathrm{Safo}^{28}$, só que mentres alí o molde formal está máis próximo ao fragmento que o inspira, neste caso requírense transformacións máis fondas, pola condición da nova creación, porque se empregan a un tempo unha gran cantidade de textos que constitúen a rede sobre a que se crea a obra dramática. En efecto, os motivos e os elementos temáticos do mundo sáfico están onmipresentes no texto de Pociña: o amor e o desamor, as escenas de exaltación dos sentidos, o matrimonio, as rivalidades entre grupos, e detrás deles translócense os fragmentos que os inspiran. Vexamos un par de exemplos. Unha das mozas do círculo, Xirina, a que máis se axusta ao estereotipo feminino do momento, que acepta como algo natural o matrimonio concertado polas familias e aprendeu xa todo o necesario para exercer a función que se espera dela, mentres borda unha peza para o seu enxoval, suspira e di: "Xa vedes, amigas: dentro de quince días estarei en Mileto, en brazos de miña nai, e dentro de dous meses en Sardis, señora por fin dunha casa miña... ${ }^{29}$. Unhas páxinas máis adiante, cando Irana lle canta

\footnotetext{
${ }^{27}$ P. 27, fr. $1 \mathrm{~V}$.

${ }^{28}$ Pociña Pérez 2005. Trátase de seis textos poéticos en estrofas sáficas inspirados por cadanseu fragmento da poeta.

${ }^{29}$ P. 34.
} 
o que compuxo para a súa voda, a moza, emocionada, manifesta: "Lembrareime de vós todas cando ma canten o día da miña voda. $\mathrm{E}$ despois aprendereina eu mesma, e cantareina pensando en ti, Irana, cando estea na miña casa, tecendo nas tardes interminabeis da primavera”. Estas últimas palabras, que inclúen a imaxe tópica da muller no ô̂kos, encamíñannos ás poesías da memoria, recordo dun amor ausente. Entre os fragmentos de Safo encontramos bastantes mostras delas motivadas pola temporalidade da convivencia coas rapazas do seu círculo. Pero a referencia ao canto e, sobre todo, a mención de Sardes, remiten indudablemente aos primeiros versos do fr. 96 c Voigt:

...en Sardes...

Moitas veces dirixindo o pensamento aquí...

Como... louvabamos...

Comparábate en todo a unha deusa,

E moito gozaba do teu canto;

Agora ela resplandece entre as mulleres de Lidia... ${ }^{30}$.

Neles é Atis o motivo da señardade dunha mujer descoñecida. O autor, nunhas trasformacións que no traizoan o sentido do orixinal, dálle identidade facendo a Xirina protagonista do recordo, pero xa non de Atis, senón de Irana, e cambia o tempo do pasado ao futuro, pero a idea básica do fragmento mantense.

Esta Xirina de Pociña, malia a súa conformidade co destino que outros trazaron para ela, recibiu de Safo unha educación que lle abriu os ollos e a fixo consciente da triste realidade do mundo feminino. As espectativas de felicidade no matrimonio que traía cando chegou á casa da poeta xa no son as mesmas. Agora descubriu outro universo de poesía e beleza e sobre todo unha idea do amor que en nada se parece á que tiña uns meses antes. A ela, como a ese pequeno grupo que forma o círculo sáfico, a educación levouna ao descubrimento de si mesma e liberou a súa alma, pero también á frustrante convicción de que pouco poden facer para cambiar a curto prazo as condicións das mulleres. Por iso, aínda que confía en adaptarse á súa futura condición de esposa e nai, está decepcionada e ten medo, pois en Sardes xunto ao seu home vivirá en función dos desexos e as necesidades da súa familia e esa identidade como persoa que descubrira esvaecerá. A expresión dos medos da rapaza concrétase na nova imaxe do noivo, antes idealizada, agora desposuída de todo idealismo:

E cada noite que pasaba, cada historia nova, cada poema nunca antes escoitado, ían empequenecendo o que no meu corazón, antes, en Mileto, fora a imaxe adorable do meu Eucarión, alto e fermoso como un Ares guerreiro. Ese

${ }^{30}$ A tradución galega de todos os fragmentos de Safo hipotextos da obra de Pociña é de Gómez Pato 2008. 
fora antes un proxecto, afondar nos seus brazos. Agora converteuse nunha dúbida, nun temor: vou a velo como é en realidade, mais ben baixo, un pouco regordecho... ${ }^{31}$.

A imaxe idealizada de Eucarión antes de que a educación obrase na moza a transformación correspóndese coa que Safo debuxa no himeneo que está compoñendo para ela e cadra cos ideais estéticos e cos tópicos xenéricos:

O noivo entra, igual que Ares, himeneo!, moito mais alto que un home alto, himeneo! ${ }^{32}$.

O contraste entre as dúas formas de ver a realidade, antes e despois do proceso educativo, exprésase con esta imaxe:

Ese é o teu problema co teu Eucarión: antes de vir aquí podías comparalo cun delicado ramallo... e agora temes atopalo semellante ao tocón gordo e torto dunha oliveira vella. Un tronco engurrado e morto, nun campo deserto ${ }^{33}$.

Tras estas palabras está o fragmento dun epitalamio da Safo histórica:

A que, amado esposo, podería con xeito compararte?

Compárote sobre todo a un delicado abrollo ${ }^{34}$.

A comparación dos esposos cunha planta nova, tradicional na poesía nupcial grega, relaciona a maduración social e biolóxica dos mozos co ciclo vexetal e inteprétase como sinal de tensión emocional. Na ficción dramática a imaxe mantén íntegras as connotacións emocionais, pero asociadas á etapa anterior á maduración intelectual da rapaza ${ }^{35}$. Unha vez producida esta e con ela a contemplación da realidade pura e dura e o desencanto, a Safo de ficción completa a imaxe coa do envellecemento esperable no ciclo natural das plantas e as súas connotacións de desolación e morte.

Ao longo da obra abundan exemplos coma estes nos que o paso do hipotexto ao hipertexto non require transformacións fondas. Emporiso son moito máis interesantes aqueles outros que supoñen un tratamento más elaborado e complexo pola disparidade de referentes e contextos.

\footnotetext{
${ }^{31}$ P. 28.

32 P. 33, fr.111 V.

${ }^{33}$ P. 72.

${ }^{34}$ Fr. 115 V.

${ }^{35}$ Vid. Aloni 1997: 188.
} 
Sinalabamos ao principio deste traballo que as reflexións sobre temas de alcance universal e os sentimentos máis sublimes se integran no marco da vida cotiá da casa das mozas. No medio do decorrer diario da vida doméstica, prodúcense as leas propias da convivencia que se van acalmando ata desaparecer por efecto da beleza da poesía, pois no fondo hai un sentir unánime no esencial, unha sympátheia no sentido máis literal e clásico do termo, entre os membros desa comunidade, cunha excepción, Filenis, unha moza de bo fondo, pero allea aos gustos e sensibilidades do grupo e polo tanto de difícil encaixe no mundo sáfico. Precisamente do seu rexeitamento deste xorden os momentos máis tensos da obra, con enfrontamentos verbais moi duros que poñen en evidencia a incompatibilidade de universos diferentes. Por outra parte, na imaxe do círculo da Safo histórica que ofrecen os fragmentos, a vida cotiá está ausente e só conta a poesía, o amor e a beleza coa súa conseguinte harmonía, que ás veces se rompe por desenganos amorosos ou traizóns. Pero cando isto ocorre, coa marcha dos elementos discordantes recupérase o acougo e a vida continúa nesa burbulla ideal, aínda que na alma queden cicatrices imborrables. Estes transos e estas persoas discordantes, fóra xa do círculo, reciben as máis duras críticas de Safo e aos fragmentos que as conteñen acudirá Pociña para ir modelando o personaxe de Filenis e deseñando as situacións incómodas que provoca. Pero ao mesmo tempo botará man doutros de ton moi diferente que inseridos nun novo contexto acadarán matices insospeitados.

$\mathrm{Na}$ súa caracterización da rapaza o autor buscará sobre todo salientar a súa desdeñosa actitude ante os elementos esenciais da educación sáfica e a repercusión que isto ten na súa concepción do amor e nas formas pouco delicadas do comportamento inadecuado que a singularizan. A discordancia co resto do grupo queda marcada xa co seu mesmo nome, pero non só por ser o único que non procede da tradición sáfica, senón tamén porque se asocia inevitablemente á prostitución, ao evocar á Filenis máis coñecida da antigüidade, a famosa cortesana de Samos, autora dun manual de prácticas sexuais, mencionada por Ateneo, xunto con Arquéstrato, como escritores de obras que enseñan a arte do bo vivir ${ }^{36}$. Non é de estrañar pois, que Pociña elexira este nome para unha rapaza cuxa afición desbocada polo sexo a leva a saltar reiteradamente as regras da casa de Safo. Este comportamento transgresor ponse de relevo mesmo antes de que pronuncie unha sola palabra. Filenis está presente en escena ao principio da obra, sentada coas demais arredor de Safo, e sen nada que a distinga aparentemente delas.

${ }^{36}$ Os nomes das outras rapazas, Gonxila, Mégara, Xirina, Irana e Telesipa, ou ben aparecen nos poemas de Safo ou os testimonios asócianos coa poeta, vid. Silva 2012: 431, n. 2. Sobre Filenis vid. Ath. 8. 235b-e. O comezo da súa obra, titulada Tratado amatorio, consérvase en P. Oxy. 2891. Aínda que Schlesier 2013 comprobou que os nomes que aparecen na poesía sáfica son especialmente frecuentes en escravas e cortesanas e poden ser indicio da verdadeira actividade do círculo, o público actual non os asocia a estas categorías sociais, senón ao mundo de beleza e amor que suxire a poeta nos fragmentos. 
Cando a mestra a manda á cociña para que traia unha limonada que as axude a aturar os rigores do estío, a tardanza e as condicións nas que volve, nerviosa e sufocada, alertan dun problema, que debía de ser habitual, a xulgar pola rapidez da reacción da poeta:

Pois si que tardaches, nena; calquera pensaría que tiveches que agardar a que madurasen os limóns... Como si non os exprimise eu mesma ao mediodía... (Miraa fixamente aos ollos). ¿Onde anda o porteiro? ${ }^{37}$.

Así, antes da súa primeira intervención oral, o espectador xa intúe que a moza ten relacións con ese home e que o encargo de Safo acaba de servirlle de excusa para un encontro amoroso. Filenis queda xa claramente marcada como elemento discordante no círculo sáfico e, en consecuencia, como fonte de problemas e discusións. Pero a súa singularidade non é imputable a elementos circunstanciais, xa que pertence a un ambiente semellante ao das demais:

Meu pai e miña nai mandáronme contigo para facer de min unha muller elegante, distinguida, como corresponde as xentes da súa clase ${ }^{38}$.

Ao contrario, está na súa propia esencia e polo tanto ten que ver con inclinacións e gustos innatos que exercen de barreira contra todo o que Safo pretende inculcarlle. Así o explica a propia Filenis dirixíndose á poeta:

Mais ti es incapaz de perdoarme que non me interesen os teus versos, nin sequera os do Poeta, nin os de Alceo, nin as cancións de Irana, nin as pinturas de Gonxila... Pois non me interesan, que lle vou facer? ${ }^{39}$.

Unha Filenis que así se manifesta ben podería merecer tamén os reproches do fragmento $55 \mathrm{~V}$, que Safo, noutra parte desta obra, afirmou ter dedicado a Atis, como xa vimos. Pero as palabras da rapaza lévannos á raíz do problema. O seu rexeitamento das manifestacións artísticas implica a imposibilidade de gozar dos efectos beneficiosos do proceso educativo do que forman parte, o que explica a súa actitude provocadora, as súas palabras insolentes, en definitiva, a súa falta de refinamiento.

Nos seus enfrontamentos co resto do grupo pola súa actitude ante o amor heterosexual e sobre todo o sexo, detectamos moi claramente a influencia dos fragmentos $16 \mathrm{~V}$ e $31 \mathrm{~V}$. Se no primero deles se contrapoñen en forma de priamel o ideal da poeta fronte a un canon tradicional:

\footnotetext{
37 P. 26

${ }^{38}$ P. 31.

${ }^{39}$ P. 31.
} 
Algúns, que unha formación de cabaleiros, outros, de infantes, Outros, de navíos, din que sobre a negra terra

Son a cousa máis fermosa; eu, aquilo que

Cadaquén ame.

a Filenis de Pociña expresa con igual eficacia a contraposición de gustos e pareceres, aínda que de forma máis agresiva, co seu rexeitamento explícito da poesía heroica e o mundo que nela se reflicte e a inclinación por placeres máis sensuais:

E mais che digo, mestra: A Iliada ponme enferma, con tantos heroes fermosos, fortes e valentes, que non deixan de matarse uns a outros, nunha carnicería interminable. E a ti non che parece ben que diga que me gusta un home, e que gozo cando me oprime co seu corpo, e entra por min como heroe victorioso ${ }^{40}$.

Filenis, así llo di Safo, é unha nova Helena, que sabe polo que debece e con tal de conseguirlo é quen, como a heroína, de desafiar cualquera norma preestablecida. A rapaza, como a Safo histórica no seu poema, reivindica a capacidade e o dereito de elexir, pero neste caso non conta coa aprobación da poeta de ficción, pero non porque non asuma que a satisfacción emocional está por encima do convencional, senón porque no caso de Filenis non se trata de amor inspirado por Afrodita, senón de instintos primarios, aínda que ela non sexa capaz de distinguir a diferenza precisamente por carecer de educación espiritual. A escasa delicadeza coa que alude ás súas experiencias e desexos provoca o escándalo e a reprobación do resto do grupo. Safo dille con desprezo, "iQue bruta es, Filenis!" ${ }^{\prime 1}$, despois de escoitar dos seus labios palabras que contraveñen os principios máis elementais da honestidade e da decencia, pois esta moza ben podería ser a destinataria do Fr.137 V que puido inspirar este aspecto do personaxe:

Mais se tiveses algún nobre ou fermoso desexo

E a lingua non remexeras para dicir algo perverso,

A vergoña non se apoderaría dos teus ollos,

Senón que falarías do que é xusto.

$\mathrm{Na}$ súa descrición das reaccións físicas que provocan os seus encontros sexuais ou as súas fantasías identificamos algúns dos síntomas do amor da Oda de Lonxino:

Iso é o amor! Perder a palabra, arderche a pel, tremer, sentir que se che abren as carnes, que morres... Iso é o amor! A min pásame cando teño un home

\footnotetext{
${ }^{40}$ P. 31.

${ }^{41}$ P. 31.
} 
enriba e sabe manexarme, e domíname, faime sentir dor e pracer, e obrígame a lanzar berros, e condúceme ao final aos cumios do gozo ${ }^{42}$.

Con estas palabras e outras intervencións de contido e ton parecido ${ }^{43}$ Pociña está deseñando un personaxe caracterizado pola súa falta de moderación e pola súa incapacidade para controlar as emocións, acorde cos estereotipos masculinos da súa época, que consideraban a muller como un ser feble e inestable. Pero a pesar da coincidencia nas reaccións corporais, mentras o eu do poema sáfico é que de facer un discurso fortemente controlado ${ }^{44}$, a intemperancia de Filenis afecta tamén á súa capacidade para controlar a súa lingua, moitas veces ferinte e ofensiva coas rapazas e sobre todo coa propia mestra, que adoito a reconvén por iso e a manda calar con pouco éxito:

Cala dunha vez por todas! Non che permito que te metas nos meus asuntos íntimos, que non che interesan en absoluto. Nin unha palabra máis. Non estou disposta a consentirche tanta insolencia ${ }^{45}$.

Nestes enfrontamentos de Filenis e Safo o autor dá forma dramática a aquilo que di o fragmento $158 \mathrm{~V}$ :

Cando se espalla no peito a ira

Á lingua que ladra en balde hai que lle poñer couto.

\section{A modo de Resumo}

Ata aquí vimos como en Unha tardiña en Mitilene Pociña, fascinado pola personalidade de Safo e pola beleza dos seus versos, nos dá a oportunidade de asomarnos á intimidade do fogar onde vive coas súas rapazas, entregada á

42 P. 30.

${ }^{43}$ Noutro momento da obra a moza expresa outra das súas fantasías sexuais nestes términos: "Eu soñei mais dunha vez que me traxinaba un negrote, e non me tocaba con dozura, non, que va! Machucábame dunha maneira..., mais deixábame tan repleta, tan saciada, tan satisfeita!". O porteiro, polo que sente unha atracción irresistible, encarna ese ideal que dá satisfacción aos seus desexos, e polo tanto imaxinámolo cun aspecto impoñente, grande, rudo, un tanto animalizado, coma aquel do epitalamio que puido servir a Pociña de inspiración para este personaxe: "O porteiro ten pés de sete brazas, / as sandalias, a pel de cinco bois, / dez zapateiros xuntos confeccionáronas” (Fr. 110c V).

${ }^{44}$ A crítica viu unha suposta contradición no fragmento ao presentar unha muller con tantos síntomas físicos e, polo tanto, sen control emocional e ao mesmo tempo amosando unha absoluta lucidez mental. Clark 2001 interpretou que Safo está a facer unha parodia das características estereotipadas que os homes lle apoñen ás mulleres. O poema, segundo a autora, mostra a perspectiva feminina sobre a construción masculina da sexualidade e do desexo feminino.

45 P.31. 
fermosa tarefa de cultivar os seus espíritos. As obras constrúense a partir dos fragmentos da autora, que se insiren na ficción dramática con técnicas diferentes, ben en forma de citas literais, ben transformados e reelaborados de diversas maneiras para construír personaxes, diálogos e situacións orixinais, que recrean ante nós o máis intemporal do mundo sáfico. Por iso rematamos facendo nosas as palabras de Horacio:

E o tempo non borrou o que Anacreonte compuxo noutro tempo; Aínda alenta o amor e viven as paixóns

Da nena eolia confiadas á súa lira ${ }^{46}$. 


\section{Bibliografía}

Aloni, A. (1997), Saffo. Frammenti. Firenze: Giunti.

Calame, C. (1996), "Sapphos's Group: An iniciation into Womanhood", in Green, E. (ed.), Reading Sappho: Contemporary Approaches. Berkeley-Los Angeles-Oxford: University of California Press, 113-124.

Clark, Ch. (2001), "The Body of Desire: Nonverbal Communication in Sappho 31 V", Syllecta Classica 12: 1-32.

Gómez Pato, R. (2008), Safo. Cantos e fragmentos. Santiago de Compostela: Edicións Positivas.

Lardinois, A. (1994), "Subject and Circumstance in Sappho's Poetry", TAPhA 124: $57-84$.

Pociña Pérez, A. (2000), Quince mulleres, quince momentos. A Coruña: Baía Edicións.

Pociña Pérez, A. (2004), "Medea en Camariñas", en Premios Pedrón de Ouro. Certames XXVII (2001), XXVIII (2002), XXIX (2003). Sada, A Coruña: Ediciós do Castro, 33-53.

Pociña Pérez, A. (2005), "Comentario a seis fragmentiños de Safo", Xistral. Revista lucense de creación poética 8: 81-82.

Pociña Pérez, A. (2007), Tecer con palabras. Santiago: Edicións Correo.

Pociña Pérez, A. (2009a), "Safo", in Pociña, A., García González, J. M. (eds.), En Grecia y Roma, III. Mujeres reales y ficticias. Granada: Universidad de Granada, 367-390.

Pociña Pérez, A. (2009b), Unha tardiña en Mitilene. Versión orixinal galega inédita.

Pociña Pérez, A. (2011), Entardecer em Mitilene, tradução do espanhol por Maria de Fátima Silva. Coimbra: Centro de Estudos Clássicos e Humanísticos.

Pociña Pérez, A. (2015), Medea. Safo. Antígona (Tres piezas dramáticas). Granada: Esdrújula Ediciones.

Romero Mariscal, L. (2012), "Safo en el teatro español contemporáneo: Atardecer en Mitilene de Andrés Pociña”, Humanitas 64: 203-217.

Schlesier, R. (2013), "Atthis, Gyrinno, and other hetairai: female personal names in Sappho's poetry", Philologus 157. 2: 199-222.

Silva, M. F. (2012), "De regresso à Lesbos de Safo". Atardecer en Mitilene de A. Pociña", in Muñoz Martín, M. N., Sánchez Marín, J. A. (eds.), Homenaje a la Profesora Maria Luisa Picklesimer (In memoriam). Coimbra: Centro de Estudos Clássicos e Humanísticos: 419-434.

Voigt, E. M. (1971), Sappho und Alkaios. Fragmenta. Amsterdam: Polak \& Van Gennep. 